DOI 10.31558/2519-2949.2018.3.13

УДК 323.1:341.1:341.2

Явір В. А., Інститут держави і права ім. В.М. Корецького НАН Украӥни

\title{
ЗАКАРПАТТЯ ЯК ОБ'СКТ ЕТНОТЕРИТОРІАЛЬНИХ ПРЕТЕНЗІЙ УГОРЩИНИ ТА РОСІЇ: ПОРІВНЯЛЬНИЙ АНАЛІЗ СТРАТЕГІЙ ТА ЦІЛЕЙ
}

У 2014 р. розпочалася відкрита фаза етнополітичної дезінтеграчії України, якій передувала багаторічна підготовка, підживлення сусідніми державами сепаратистських настроїв у середовищі наиіональних меншин. В жодній концепиії, стратегії розвитку держав не зустрічаємо намірів, які стосуються участі в дезінтеграційних проектах, однак на практиці виявляється, що зовнішня етноначіональна політика багатьох краӥн містить дезінтеграційну складову щодо сусідніх держав, до яких має етнотериторіальні претензї і де проживає ї̈ національна меншина. Саме Закарпаття, в якому переплелися інтереси Угорщини та Росії, у випадку ігнорування дезінтеграиійних чинників та деструктивної діяльності ији держав може стати наступним регіоном, над яким Украӥна втратить контроль.

Закарпаття є об'єктом етнотериторіальних і етнополітичних претензій Угорщзини та Росії, які діють в окремих випадках злагоджено, переслідуючи різні иілі та застосовуючи різні стратегії, що в кінцевому підсумку дестабілізують етнополітичну ситуацію в регіоні та сприяють поширенню сепаратистських тендениій. Офіційною метою Угорщини є формування угорської територіальної автономії в межах Закарпатської області. Угорщина відкрито проводить поступову етнополітичну інтеграцію населення регіону, жорстко відстоюючи та захищаючи права етнічних угориів. Росія, натомість, приховано використовує русинів, сприяючи політизачії та радикалізачї̈ вимог представників цієї етнічної групи, заохочуючи їх до територіального самовизначення. На відміну від Угорщини, Росія не має спільного кордону з Закарпаттям, тому ї̈ мета полягає не в етнополітичній інтеграчиї регіону, а в дестабілізаиї̈ Закарпаття, у продовженні прочесу дезінтеграчії Украӥни, послабленні позицій держави в етнополітичному конфлікті на Півдні та Сході, в погірменні перспектив деокупації Донбасу та Криму.

Ключові слова: Закарпаття, сепаратизм, етнополітична дезінтеграція

У 2014 р. розпочалася відкрита фаза етнополітичної дезінтеграції України, якій передувала багаторічна підготовка, підживлення сусідніми державами дезінтеграційних тенденцій та сепаратистських настроїв у середовищі «своїх» національних меншин. Крим і Донбас стали об'єктом уваги Російської Федерації через пострадянську та російську ідентичність значної частини населення, яке лояльно ставилося до Російської Федерації. Ця держава у більшості населення цих етнополітично проблемних регіонів асоціювалася з Радянським Союзом як його правонаступниця, а перебування у складі України маркувалося як «тимчасове» або ж «непорозуміння». Етнонаціональна самоідентифікація та тривала інформаційно-пропагандистська робота 3 інтеграції населення в «русский мир» зіграла вирішальну роль у тому, що саме ці регіони України були обрані майданчиками випробування та застосування технології етнополітичної дезінтеграції суверенної держави.

Актуальність роботи пояснюється тим, що не лише Російська Федерація вдається до цієї політичної технології шляхом втручання у внутрішні справи України, формування відцентрових настроїв в середовищі власної національної меншини через ЗМI, фінансування громадських організацій національних меншин, фактичною метою діяльності яких $є$ порушення територіальної цілісності України та етнополітична інтеграція регіону проживання власної національної меншини до складу материнської держави. Угорщина та Румунія проводять подібну політику на Закарпатті та Буковині відповідно. Особливий інтерес представляє Закарпаття - регіон, в якому переплелися інтереси двох експансіоністськи налаштованих щодо України держав - Угорщини та Росії.

В жодній концепції, стратегії розвитку держав не зустрічаємо намірів, які стосуються дезінтеграції держави або іiі участі в дезінтеграційних проектах. Однак на практиці виявляється, що зовнішня етнонаціональна політика багатьох країн містить дезінтеграційну складову щодо сусідніх держав, до яких має етнотериторіальні претензії і де проживає іiі національна меншина. Дослідження цієї проблеми має не лише теоретичну, а й прикладну спрямованість - саме Закарпаття у випадку 
ігнорування дезінтеграційних чинників, експансіоністської зовнішньої етнополітики сусідніх держав може стати наступним регіоном, над яким Україна втратить контроль.

Мета дослідження полягає у вивченні етнотериторіальних зазіхань Угорщини та Росії на Закарпаття, порівняльному аналізі стратегій та цілей цих двох держав. Незважаючи на те, що Закарпаття як етнополітично проблемний регіон, територія поширення сепаратистських тенденцій, був об'єктом вивчення багатьох вчених (С. Асланова, К. Вітмана, В. Дівак, В. Євтуха, І. Зварича, О. Картунова, В. Котигоренка, І. Кресіної, Л. Лойко, О. Майбороди, В. Наконечного, М. Обушного, М. Панчука, Ю. Тищенко, М. Товта), порівняльний аналіз цих аспектів зовнішньої етнополітики Росії та Угорщини щодо Закарпаття, принаймні з урахуванням останніх подій та реалій, ще не проводився.

Почнемо дослідження бекграунду об'єкту етнотериторіальних та етнополітичних претензій Угорщини та Росії, в якому переплелися зовнішні інтереси цих держав. Закарпаття $є$ історикогеографічним регіоном, розташованим на південному заході України, який займає $2,1 \%$ від усієї території держави і збігається з територією сучасної Закарпатської області. Одразу зазначимо, що Закарпаття межує з Польщею, Словаччиною та Угорщиною - протяжність кордону з останньою складає 130 км. Цей об'єктивний факт суттєво посилює позиції Угорщини у претензіях на Закарпаття, але послаблює позиції Росії, яка не має безпосереднього кордону з регіоном. Позаяк всі території, які були раніше відокремлені від України внаслідок відкритої або прихованої агресії цієї держави - Крим та Донбас - межували з Російською Федерацією. I саме у зв’язку з незаконним переміщенням зброї, військових підрозділів через неконтрольовану ділянку сухопутного або морського кордону Україні не вдалося покласти край сепаратистським проявам - діям самопроголошеної влади та відновити контроль Кримом та Донбасом.

Відсутність спільного кордону Росії з Закарпаттям вже саме по собі свідчить про різні цілі Угорщини та Росії. Якщо в Угорщини є перспективи як етнополітичної, так і територіальної інтеграції Закарпаття до свого складу, то в Росії їх немає. 3 цього випливає, що завдання Росії полягає не в подальшій інтеграції регіону, а в дестабілізації етнополітичної ситуації в Україні, послабленні позиції держави в етнополітичному конфлікті на Півдні та Сході, в погіршенні перспектив деокупації Донбасу та Криму. С. Асланов вважає етнополітичну дезінтеграцію України прямим наслідком етнополітичної нестабільності. На думку вченого, Російська Федерація на нинішньому етапі розвитку $\epsilon$ головним джерелом етнополітичної нестабільності на пострадянському просторі, оскільки заохочує сепаратистські рухи, підтримує відцентрові тенденції у пострадянських країнах з метою утримання їх під своїм геополітичним контролем та недопущення їх інтеграції до ЄС та НАТО [1, с. 5].

Перешкоджання євроатлантичній інтеграції України видається також метою Угорщини, яка використовує питання згортання освіти мовами національних меншин у середній школі України як привід для блокування вступу України до НАТО і СС. Уряд Угорщини, вимагаючи непідписання Президентом України Закону «Про освіту», навіть вирішив блокувати всі подальші рішення Європейського союзу, спрямовані на зближення з Україною. Угорщина, зокрема, пообіцяла ініціювати перегляд Угоди про асоціацію між Україною та ЄС. Також Будапешт заблокував роботу Комісії Україна-НАТО з питань оборони. Навіть незважаючи на те, що 11 держав-членів НАТО висловили незгоду з діями Угорщини щодо блокування євроатлантичних ініціатив України через освітню реформу. «Угорщина зловживає принципом консенсусу і не мала б використовувати механізми Північноатлантичного Альянсу для тиску на Київ», - зазначається у листі 11 союзників до угорського уряду [2]. Однак такі дії свідчать про опосередковану ціль Угорщини: домогтися збереження в Україні середньої освіти угорською мовою в комунальних закладах освіти на тлі узгодження дій з Російською Федерацією з тиску на Україну.

Конфлікт між Україною та Угорщиною виник внаслідок того, що в контексті проведення освітньої реформи в Україні 5 вересня 2017 р. Верховна Рада України ухвалила Закон України «Про освіту», ст. 7 якого визначає мовою освітнього процесу в закладах освіти України державну мову. Відмова від одномовної середньої освіти (лише мовами національних меншин) була продиктована тим, що представники національних меншин в місцях компактного проживання, в тому числі на Закарпатті, за результатами ЗНО багато років поспіль демонструють дуже низький рівень володіння державною мовою. Одномовна освіта мовою національних меншин тривалий час слугувала підгрунтям для відцентрових тенденцій в Україні, позаяк представники національних меншин не інтегрувалися в українське суспільство через незнання державної мови і пов'язували свою освітню та професійну діяльність виключно з етнічною батьківщиною [3, с. 32]. Тому 
міністр закордонних справ України, спростовуючи закиди Будапешта, заявив, що позиція України полягає не в тому, щоб обмежити навчання мовами національних меншин, а в оволодінні представниками національних меншин державною мовою. «Інакше громадяни України, де розмовляють здебільшого угорською або румунською, не зможуть вступити до університету, не зможуть служити в армії або зайняти державну посаду... I це також питання національної безпеки», - наголосив П. Клімкін [4].

Переконані, що незнання державної мови сприяє ізоляції національних меншин, їх орієнтації виключно на етнічні батьківщини, поширенню сепаратистських настроїв, що в кінцевому підсумку може загрожувати територіальній цілісності України. В. Наконечний також вважає, що «свідоме підвищення Будапештом градусу напруги, використання інформаційно-пропагандистських дій, провокування політико-дипломатичних скандалів, щоб максимально загострити ситуацію та примусити Київ піти на поступки в питанні гарантування угорській спільноті Закарпаття права навчання рідною мовою виступають ширмою і підгрунтям для більш серйозних речей - перегляду адміністративно-територіального устрою Закарпатської області України та утворення окремого угорського адміністративно-територіального автономного району 3 компактним проживанням угорців, який межує з Угорщиною, як проміжного завдання угорського іредентизму в Україні» [5, с. 106]. Росія також висловила протест проти відмови від одномовної середньої освіти мовами національних меншин в Україні, але таких легітимних міжнародних важелів тиску на Київ, на відміну від Угорщини, країна-агресор не має.

Національний склад Закарпаття, на перший погляд, переконливо свідчить на користь збереження територіальної цілісності України і не сприяє реалізації дезінтеграційних стратегій Росії та Угорщини, які приховано або відкрито висувають етнотериторіальні претензії до цього регіону. Згідно 3 даними перепису населення 2001 р. українці становлять більшість - 80,5\%, найбільшою національною меншиною $є$ угорці $-12,1 \%$, росіяни займають четверту позицію $-2,5 \%$. Однак ситуація ускладнюється тим, що, по-перше, дані перепису населення занадто застарілі і не відображають реальної картини етнонаціонального складу Закарпаття; по-друге, угорська національна меншина вирізняється компактним проживанням у містах регіону та згуртованістю; потретє, Російська Федерація діє не через російську національну меншину, а через русинів - етнічну групу, яка нетривалий час мала власну державу на Закарпатті - Карпатську Україну (1939 р.) i за підтримки ззовні погрожує відокремленням від України.

Угорщина вже давно вимагає від України розширення прав угорців та їх автономізації в межах Закарпатської області, підживлюючи дезінтеграційні настрої серед угорського населення області. В середині 1990-х рр. держава проголосила, що несе відповідальність за угорські спільноти за кордоном і збирається їх всіма способами захищати. Навіть тими, які суперечать принципам невтручання у внутрішні справи інших держав, збереження їх територіальної цілісності. Прем'єрміністр Угорщини зажадав надання українським угорцям автономії та подвійного громадянства. «Становище 200 тисяч угорців за національністю, які живуть в Україні, надає цьому питанню особливої гостроти. Угорська громада там повинна отримати подвійне громадянство, всі права національної спільноти, а також вона має отримати можливість самоврядування», - наголосив, виступаючи в угорському парламенті, В. Орбан [6]. Тож, метою Угорщини є формування угорської територіальної автономії в межах Закарпатської області.

Натомість Росія діє більш прихованими методами. В 2014 р. русини звернулися до Росії 3 проханням визнати незалежність Карпатської Русі (в окремих документах Закарпатська, Підкарпатська) від України. Відкритий лист до Президента РФ із закликом до відновлення історичної справедливості - дорадянського статусу Республіки Підкарпатська Русь оприлюднив П. Гецко, координатор мережевого русинського руху, який проголосив себе прем'єр-міністром Республіки Підкарпатська Русь. У зверненні стверджувалося, що «русини краю не хочуть входити до складу такої України, де шириться галицький нацистський безлад, що загрожує русинам етнічними чистками». Самопроголошений прем'єр звернувся 3 до В. Путіна 3 проханням захистити русин та провести миротворчу операцію для «визнання відновленої державності Республіки Підкарпатська Русь та нейтралізації галицького нацизму в Закарпатті» [7]. Інші русинські організації заперечили причетність до цього звернення, назвавши лист провокацією, яка дискредитує русинський рух.

Використання Російською Федерацією русинського руху для дестабілізації етнополітичної ситуації в Закарпатській області стало продовженням етнополітичної технології дезінтеграції України, розпочатій в Криму та на Донбасі. Це підтверджують факти викриття та затримання групи 
осіб, які курувалися російськими спецслужбами і готували створення самопроголошеної «Республіки Підкарпатської Русі» на листопад 2014 р. Сценарій ймовірного розгортання подій був подібний до Донбаського варіанту дезінтеграції, оскільки передбачав захоплення місцевих органів державної влади та інших стратегічних об'єктів диверсійними групами під виглядом місцевої самооборони самопроголошеної республіки [8]. Це детально розроблений проект сепаратизації регіону, де чітко розписані заходи відокремлення Закарпаття від України. Основою його реалізації мали стати псевдорусинські організації як радикального, так і мирного гатунку, які повинні були організувати акції протесту, захоплення адмінбудівель, домагатися федералізації за допомогою референдуму. Республіка Підкарпатська Русь після самопроголошення повинна була видати декрети «Про поширення повноважень Уряду РПР на територію Закарпатської області України», «Про перепідпорядкування Уряду РПР всіх структур державного управління, місцевого самоврядування Закарпатської області, банківських, фінансових, економічних структур».

Однак етнополітична технологія не спрацювала, оскільки в Закарпатській області: 1) більшість населення не належать до русинської етнічної групи; 2) абсолютна більшість населення, включаючи самих русин, не має наміру відокремлюватися від України. Насправді, головні вимоги русин лежить у площині набуття статусу національної меншини в Україні, а не формування територіальної автономії. Лідери русинського руху неофіційно заявляють, що набуття Закарпатською областю автономії - це програма максимум, тоді як програма мінімум - отримання статусу національної меншини та забезпечення всіх прав, які з нього випливають. Як зауважує К. Вітман, «якби українським законодавством було передбачено механізм самоідентифікації групи громадян як національної меншини, русинам не довелося б іти на такі крайні політичні заходи, демонструючи сепаратистські тенденції» [9, с. 664].

На відміну від Росії, Угорщина діє прямо через власну національну меншину, при цьому виявляючи турботу та інвестуючи у розвиток всього Закарпатського регіону. Під час виступу 3 нагоди 20-ої річниці підписання Рамкової конвенції про захист національних меншин міністр закордонних справ Угорщини дорікнув Раді Свропи, що вона більше переймається ситуацією з мігрантами, ніж закарпатськими угорцями, чиї права начебто грубо порушуються в Україні [10]. Угорщина закликала направити місію ОБСС на Закарпаття після того, як у вікно будівлі обласного офісу організації закарпатських угорців в Ужгороді кинули «коктейль Молотова» [11]. Товариство угорців Закарпаття, на офіс якого було скоєно загалом два напади, після офіційної заяви Будапешта також закликало розгорнути в області постійну місію ОБСЄ [12]. Однак в ОБСЄ, вивчивши ситуацію в регіоні, заявили, що ситуація на Закарпатті спокійна. Глава МЗС України також не побачив підстав для направлення спостерігачів у регіон, закликавши саме Російську Федерацію припинити російські провокації в області. П. Клімкін підозрює, що Росія причетна до нападів на угорську меншину в такий спосіб провокуючи загострення україно-угорських відносин [13].

Про те, що завданням Угорщини є етнополітична інтеграція Закарпаття в угорський простір свідчить рішення про запровадження посади урядового уповноваженого, відповідального за розвиток Закарпаття. МЗС України зажадало пояснень від Будапешта і пообіцяло заборонити в’їзд цьому угорському чиновнику до України, оскільки до його компетенції віднесено частину суверенної території України і тому така посада сприймається як втручання у внутрішні справи. «Жодні сепаратистські наміри не приховуються на задньому плані, метою є лише підтримка людей, які проживають на Закарпатті, незалежно від національності», - відповів на закиди призначений на цю посаду І. Грежа [14].

Угорщина посилається не лише на кількість угорської національної меншини в регіоні, а також на те, що Закарпаття належало до іï складу в 1939-1944 pp. Українськими істориками цей період розглядається як угорська окупація Закарпаття. Натомість до Російської Федерації Закарпаття в ХX ст. не належало, якщо не розглядати цю державу правонаступницею СРСР, до складу якого входило Закарпаття у складі України (1944-1991).

Слід зазначити, що Угорщина довгий час проводить політику спрощеного надання українцям угорського походження свого громадянства (на 2017 р. українцям було видано понад 100 тис. угорських паспортів), незважаючи на те, що подвійне громадянство заборонене українським законодавством. А нещодавно Угорщина передала Закарпатській області у вигляді гуманітарної допомоги партію рідкого хлору в умовах його гострого дефіциту в Україні для знезараження питної води. Ці дії сусідньої держави вказують на ознаки поступової інтеграції Закарпаття, створення привабливої перспективи отримання громадянства, вивчення угорської мови, налагодження зв' язків. 
Перспективи подальшого дослідження проблеми залежать від зовнішньоетнополітичної діяльності Росії та Угорщини та полягають в моніторингу активності цих держав та їх організацій на Закарпатті зокрема. Наразі Закарпаття є об'єктом етнотериторіальних і етнополітичних претензій Угорщини та Росії, які діють в окремих випадках злагоджено, переслідуючи різні цілі та застосовуючи різні стратегії, що в кінцевому підсумку дестабілізують етнополітичну ситуацію в регіоні та сприяють поширенню сепаратистських тенденцій в середовищі національних меншин. Угорщина відкрито проводить поступову етнополітичну інтеграцію населення регіону, жорстко відстоюючи та захищаючи права етнічних угорців. Росія натомість приховано використовує русинів, сприяючи політизації та радикалізації вимог представників цієї етнічної групи. Завдання Москви полягає у продовженні дезінтеграції України та послабленні позицій Києва в етнополітичному конфлікті на Сході та Півдні, в погіршенні перспектив деокупації Донбасу та Криму.

\section{Бібліографічний список:}

1. Асланов С. А. Етнополітична стабільність держави: політико-правовий аналіз: монографія. Ужгород: Лipa, 2016. $464 \mathrm{c}$.

2. Gábor László Z., László A. NATO-érdekeket sértünk // Magyar Nemzet. URL: https://mno.hu/kulfold/natoerdekeket-sertunk-2432077.

3. Явір В. А. Освіта мовами національних меншин в Україні: дезінтеграційні виклики // S.P.А.C.Е. 2017. Вип. 7. С. 29-32.

4. П. Клімкін щодо претензій Угорщини: Закон про освіту нікого не обмежує // Європейська правда. URL: http://www.eurointegration.com.ua/news/2017/09/29/7071661/.

5. Наконечний В. С. Угорський іредентизм в контексті національної безпеки України // Держава і право. Серія Політичні науки. 2017. Вип. 78. С. 95-107.

6. Угорщина має намір легально відібрати Закарпаття // Волинські новини. URL:

https://www.volynnews.com/news/policy/uhorshchyna-planuye-lehalno-vidibraty-zakarpattia-infohrafika/.

7. Забытый народ обратился к Президенту Российской Федерации // Руська правда. URL: http://www.ruska-pravda.com/novosti/34-nv-politika/24080-zabyty.html.

8. СБУ: Спецслужби РФ планували створити в Україні ще чотири «народні республіки» // УHIAH. URL: http://www.unian.ua/society/1014227-sbu-spetsslujbi-rf-planuvali-stvoriti-v-ukrajini-sche-chotiri-narodni-respublikisered-yakih-kijivska.html.

9. Вітман К. М. Русинське питання: спроби законодавчого врегулювання // Держава і право. 2010. Вип. 50. С. 660-665.

10. Hungary calls on Council of Europe to take protection of European minorities seriously // Ministry of Foreign Affairs and Trade. URL: http://www.kormany.hu/en/ministry-of-foreign-affairs-and-trade/news/hungary-calls-oncouncil-of-europe-to-take-protection-of-european-minorities-seriously.

11. Угорщина наполягає на місії ОБСЄ на Закарпатті // Свропейська правда. URL: https://www.eurointegration.com.ua/news/2018/02/5/7077105/.

12. Az ukrán hatóságoknak garantálniuk kell a kárpátaljai magyarok biztonságát // Külgazdasági és Külügyminisztérium. URL: http://www.kormany.hu/hu/kulgazdasagi-es-kulugyminiszterium/hirek/az-ukranhatosagoknak-garantalniuk-kell-a-karpataljai-magyarok-biztonsagat.

13. Клімкін: Росія фактично веде третю світову війну // BBC Ukraine. URL: https://www.bbc.com/ukrainian/features-43412789.

14. Угорський уповноважений по Закарпаттю не зрозумів обурення Києва щодо свого призначення // Європейська правда. https://www.eurointegration.com.ua/news/2018/08/3/7085210/.

Yavir. V. A. Transcarpathia as an object of ethnoterritorial claims of Hungary and Russia: a comparative analysis of strategies and goals

In 2014, an open phase of ethnopolitical disintegration of Ukraine started, which was preceded by long-term preparation, feeding by neighboring states of separatist sentiments among ethnic minorities. It turns out that the foreign ethnopolitics of many countries contains a disintegration component toward neighboring states with ethno-territorial claims. It is Transcarpathia, where the interests of Hungary and Russia intertwined, in case of ignoring the disintegration factors and the destructive activity of these states, may become the next region over which Ukraine will lose control.

Transcarpathia is the object of ethnoterritorial and ethnopolitical claims of Hungary and Russiacountries, pursuing various goals and applying different strategies that ultimately destabilize the ethnopolitical situation in the region and promote the spread of separatist tendencies. The official aim of Hungary is to form Hungarian territorial autonomy within the Transcarpathian region. Hungary is openly pursuing a gradual ethno-political integration of the region's population, rigorously protecting the rights of ethnic Hungarians. Russia, on the other hand, uses Rusyns secretly, promoting politicization and 
radicalization of the demands of this ethnic group, encouraging them to territorial self-determination. Unlike Hungary, Russia does not have a common border with Transcarpathia, therefore its goal is not to integrate the region, but to destabilize the Transcarpathia, to continue the process of disintegration of Ukraine, to weaken the position of the state in the ethnopolitical conflict in the South and East, to undermine the prospects for the de-occupation of the Donbas and Crimea.

The prospects for further studying of the issue depend on the external ethno-political activity of Russia and Hungary and are grounded in monitoring the activity of these states and their organizations in Transcarpathia since the positions of national minorities - Hungarian and Ruthenian are not independent, but mostly determined from the outside.

Key words: Transcarpathia, separatism, ethnopolitical disintegration 